2(1)(2022) 44-53

Journal homepage: https://ojs.unikom.ac.id/index.php/injuratech

\title{
Design of a Customizable Preview Feature on Clothing Website
}

\author{
Eddy Soeryanto Soegoto', Muhammad Ananta Hafidz ${ }^{2 *}$, Rania Febiananda ${ }^{3}$, \\ Daniel Maruli $^{4}$
}

1Departemen Manajemen, Universitas Komputer Indonesia, Indonesia 2Departemen Teknik Informatika, Universitas Komputer Indonesia, Indonesia

3,4Departemen Desain Komunikasi Visual, Universitas Komputer Indonesia, Indonesia

Email: *ananhafidz346@mahasiswa.unikom.ac.id

\begin{abstract}
Clothing trends that always change over time, and the tight competition in the clothing business make producers have to rack their brains so that the business they run has additional points for consumers, ranging from changes in design, use of materials, colour selection to the promotion section. The purpose of this research is to create a custom clothing feature on the website that is useful for consumers who have a special desire for the clothes they want to buy. The research method used in this research is descriptive analysis with a quantitative approach. The results show that the addition of the Custom Clothing feature can provide better clothes ordering experience on a digital platform that can be accessed through each computer. The main concept of this feature is a choice of sizes and pieces of clothing that can be chosen without thinking about stock availability. In the end, this feature is here to help consumers who have a special desire for the clothes they want to buy, so that consumers who have special desires can have clothes from that brand without thinking about stock availability.
\end{abstract}

\section{Introduction}

Clothing is one of the primary human needs in addition to food and shelter. At first, clothing was only used to protect the human body from the scorching heat of the sun or the cold. But along with the development and civilization of human culture, clothing also aims to add aesthetics and can cover shortcomings, so clothing and accessories are needed [1-5]. Clothing trends that always change over time, and fierce competition in the clothing business make manufacturers have to rack their brains so that the business they run has additional points for consumers, starting from changes in design, use of materials, color selection to the marketing 
2(1)(2022) 44-53

Journal homepage: https://ojs.unikom.ac.id/index.php/injuratech

department [6-10]. Today's marketing has adapted to the environment and consumers, marketing must get used to a time when consumers are the initial priority of business [11-15]. Now, consumers can receive data from various sources and have greater creativity, they have become standardization. In other words, customers pay for goods or services not only for functional needs, but also for identities that help show their identity [16-20]. Therefore, mass customization is an inevitable trend in the development of the clothing industry. Mass customization can efficiently solve the problem of large inventory in the traditional clothing industry. This participatory design requires technology to be able to reach everyone's wishes, businesses must adapt to the behavior of consumers who no longer want a finished product [3]. (Hart,1996). Four significant types of customizations allow customers to submit their requirements to the factory prior to production: (i) Adaptive customization: the company produces standard products [2]. He leaves the option to the customer to modify some of the product features to some extent. (ii) Collaborative customization: the manufacturer works closely with the customer to accept all possible requirements and creates the perfect product to answer the customer's needs. (iii) Cosmetic customization: this type of customization involves standard products and offering other products for different customer representations; (iv) Transparent customization: the company produces a unique item for its customer without notifying the customer that the item has been customized [4].

The purpose of this study is to help consumers who have special desires for the clothes they want to buy, so that consumers who have special desires can have clothes from that brand without thinking about stock availability.

\section{Method}

This study uses descriptive analytical research methods and by using a qualitative approach to convey the research design [21-25]. We use figma and adobe illustrator applications for system design with the prototype system development method. The prototype represents the product model to be built or simulates the structure, functionality and operation of the system [26-28]. Interactive communication from users is required to support this development method. Therefore, users can provide more input for this development method. In the development of systems that focus on the user interface, this method is very useful. Therefore, the communication relationship between developers and application users is very important to maintain so that application specifications are also good [29]. The prototyping system development method is shown in Figure 1. 


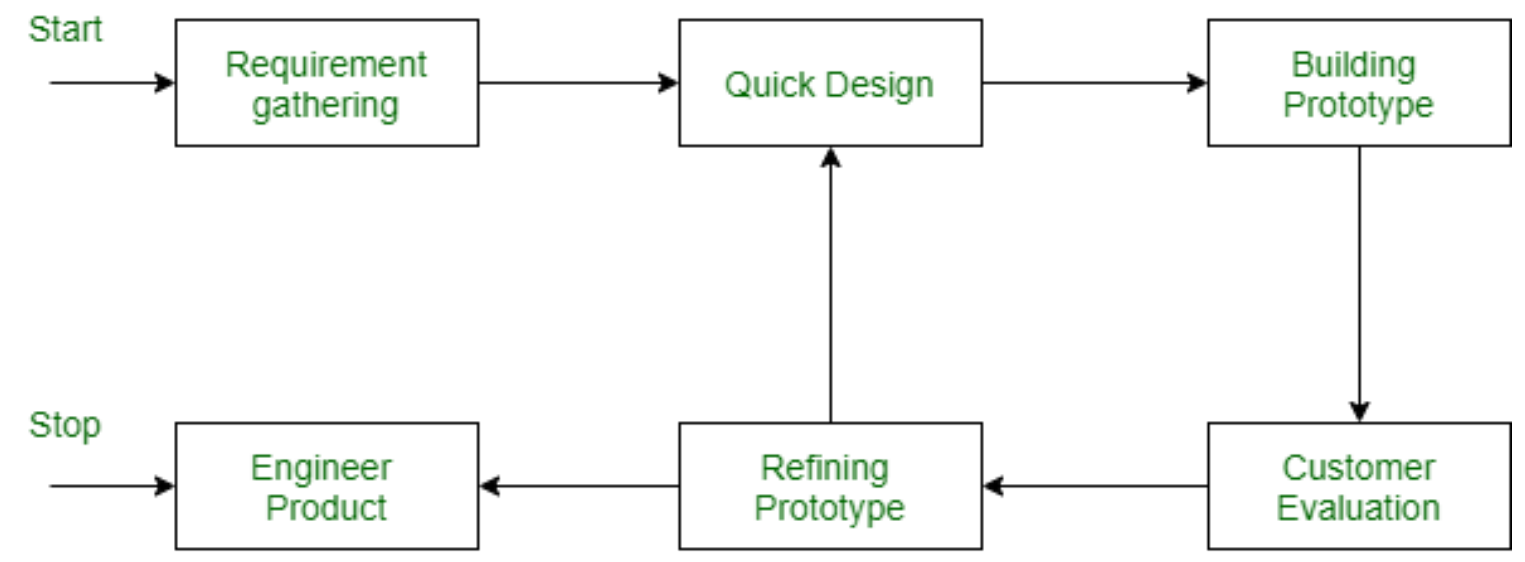

Figure - Prototype Model

Figure 1. System Development Life Cycle Prototype

Requirement's identification is carried out as the first step of the prototype system. User interviews conducted at this stage aim to obtain information about the things that will be entered into the system to be created. After the interview stage is carried out, a prototype design will be made by the developer as an initial design that will be used as discussion material for users to do better development. After the initial prototype has been successfully created, the user will review the prototype in order to provide criticism or suggestions on the design that has been made. After receiving criticism or suggestions about the prototype, the developer can improve its prototype until the prototype is finished [7-10].

\section{Results and Discussion}

\subsection{Identifying Requirement}

This custom clothing application is designed to meet customer needs that differ from what is offered with ready stock items. developers do simple research to find out and map what needs to be included as features in the application. This custom clothing application is equipped with features of custom sizes and colors for all shirts or pants, and also the addition of accessories such as pockets for several types of clothes and pants, so customers can freely choose what they want. The custom application menu structure is shown in Figure 2. 


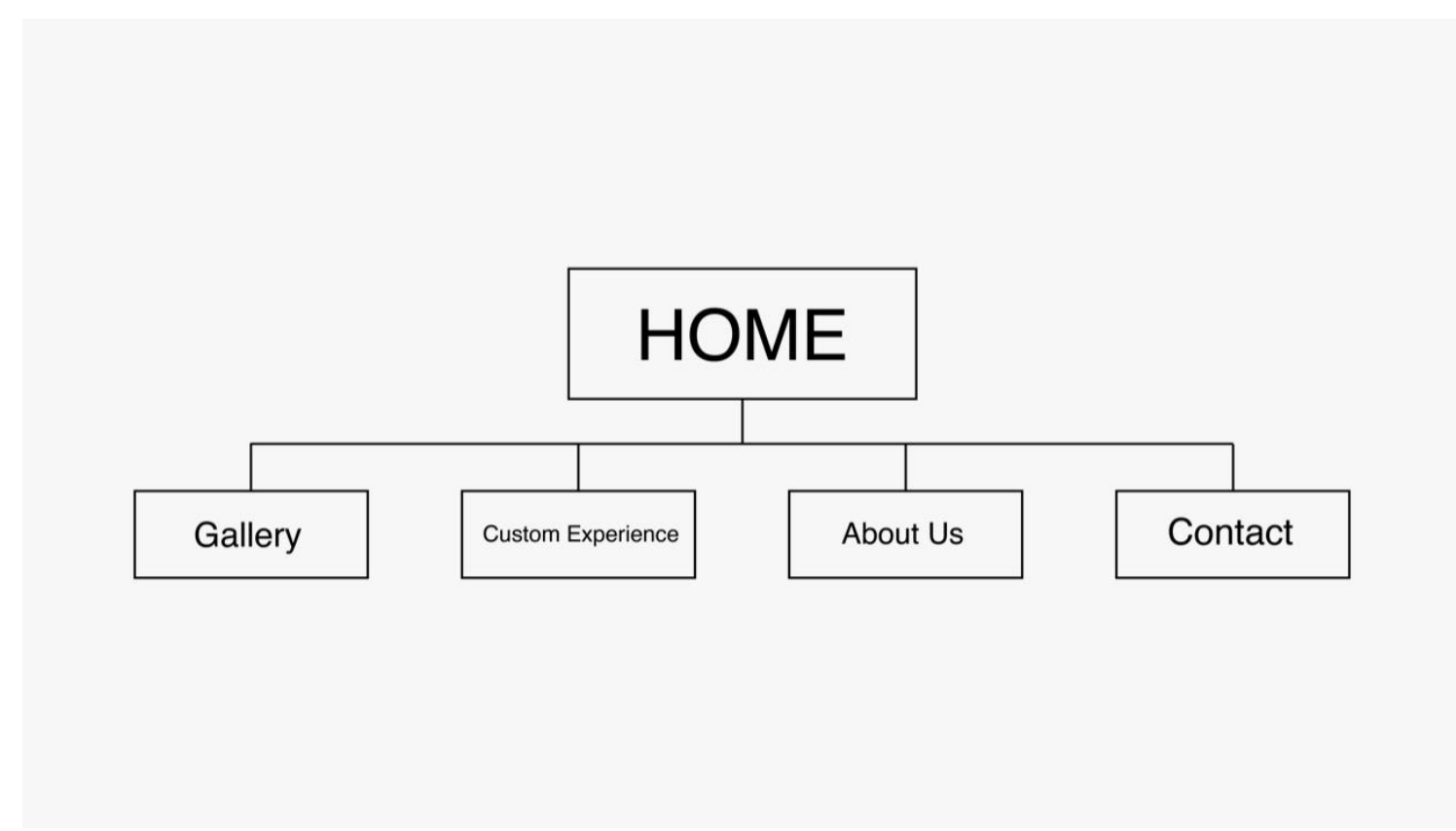

Figure 2. Custom Application Menu Structure

Figure 2 shows the design of the Custom Clothing Application menu structure. The Home menu which is the main menu contains the login feature and there is a navigation bar containing 4 sub menus, namely the about us menu, size guide, team, and contact us.

\subsection{Developing the Initial Prototype}

In the early stages of prototyping, the developer designs the front page of the Custom apparel application (see Figure 3) [11-15]. The Home screen contains the custome outfit Application logo, the application slogan and the login feature. 


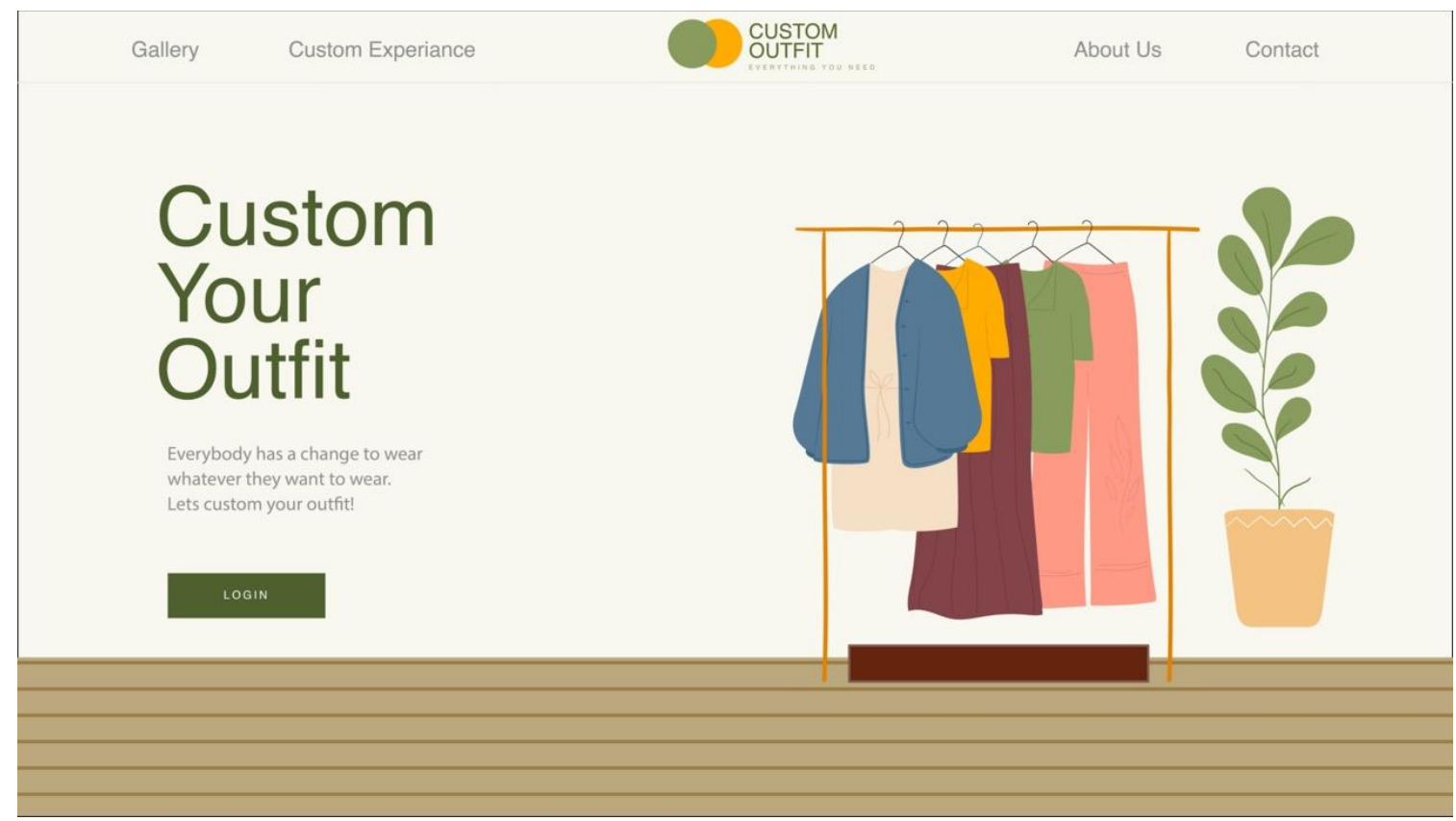

Figure 3. Welcome Page Custom Outfit Application

Figure 3 shows the start page of the Custom Outfit application. From the slogan, it can be seen that the name of this application's mission is to make it easier for consumers to wear what they want to wear. The main Custom Outfit Application page is shown in Figure 4. 


\section{International Journal of Research and Applied Technology}

2(1)(2022) 44-53

Journal homepage: https://ojs.unikom.ac.id/index.php/injuratech

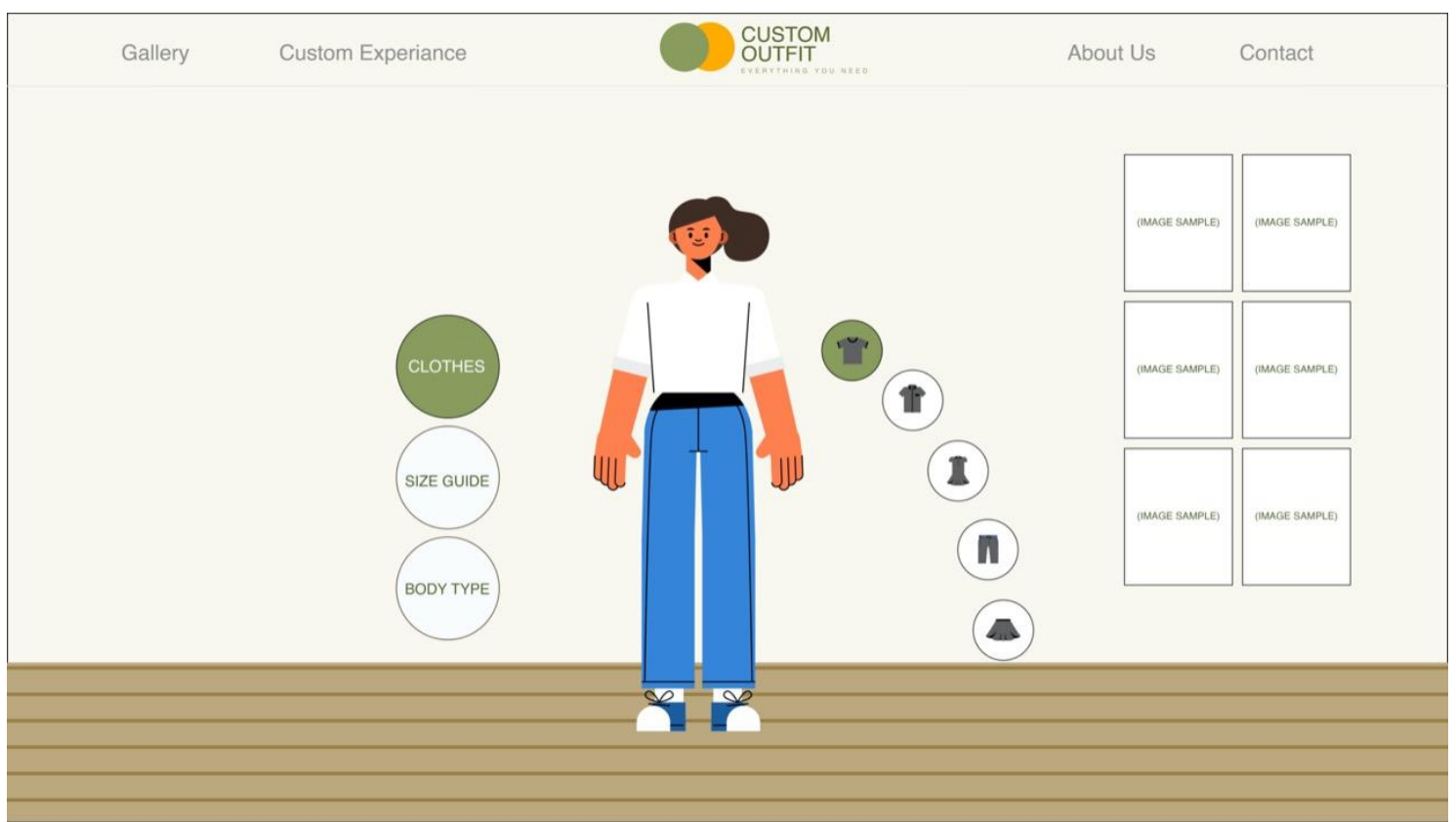

Figure 4. Home page Custom Outfit Application

On the main page, there are 3 options, namely the clothes section, size guide and body type, in the clothes section there is an option to choose the type of clothing, there are shirts, shirts, dresses, trousers and skirts. and on the right, there is a selection box to choose the type of accessories or the type of clothing cut.

\subsection{Testing the Prototype}

The explanation of the three menus above is shown in Figure 5. 


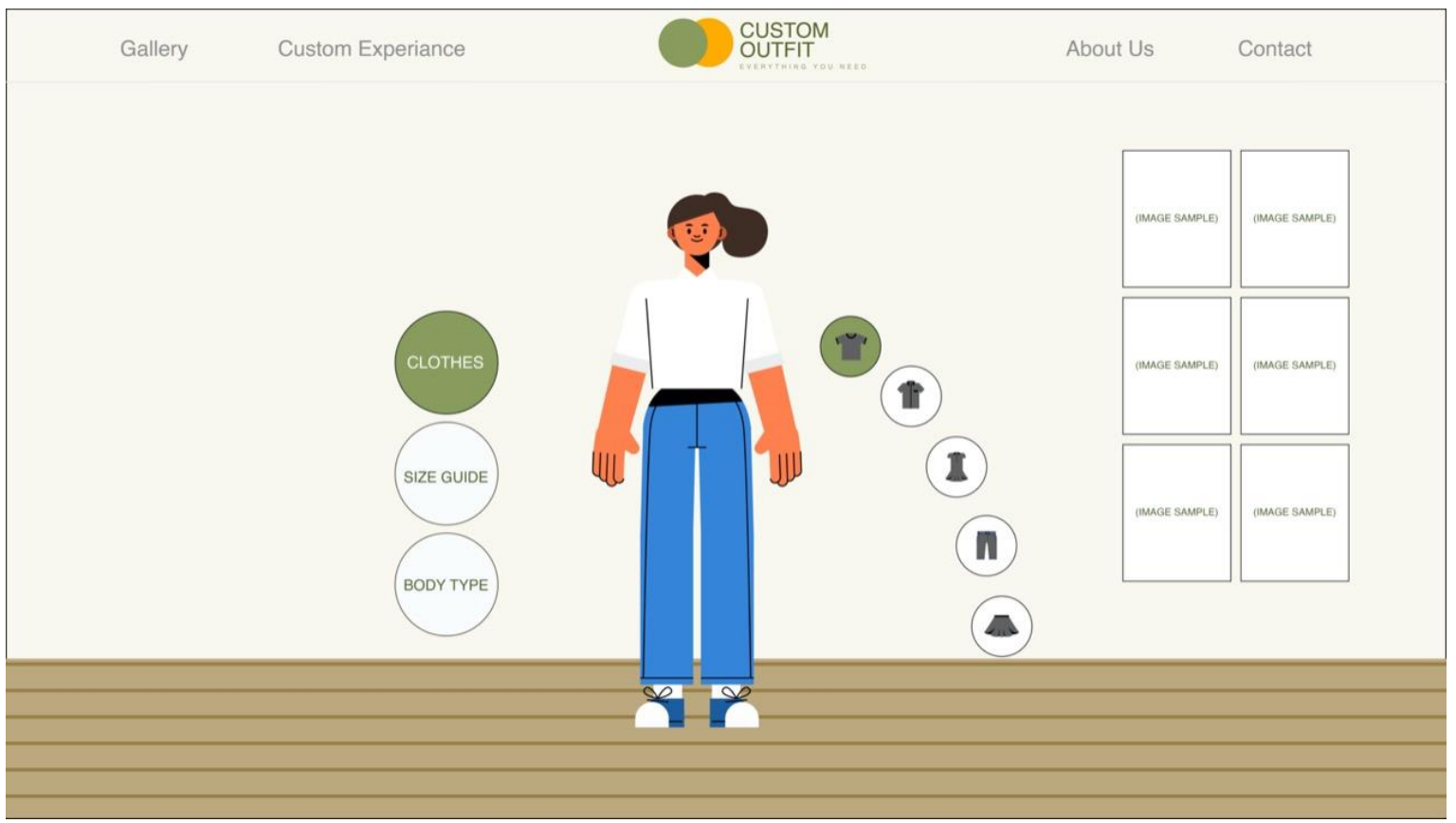

Figure 5. Custom Guide Page

Figure 5 shows a custom clothing page. On this page, customers will be given the option to choose what type of clothing they want to customize, and on the right side there is a box whose function is to store photo assets, types of accessories that can be added for clothing customization, and there is also an option to view size guide and body type. to be a benchmark for customers when doing customization.

The Custom Outfit application prototype is designed to provide more flexible choices for consumers who want to be different or have special needs. This application provides a size guide, body type, and various types of clothing which of course can be customized regarding new cases in a certain area. This application is also designed because many people have to have to shop online because of the pandemic. the result of this research is an application prototype that does not exist in previous studies [31-32]. So that in the end the results of this research become the latest innovation for online clothing business actors so that they can be developed even better.

\section{Conclusion}

In the current business era, business is very growing, clothes where many boutiques appear or distribution. The custom outfit application is designed to be a model for today's outfit buying applications. In this application there is provides a size guide, body type, and various types of clothing which of course can be customized regarding new cases in a certain area.

\section{Acknowledgement}

We would like to thank Universitas Komputer Indonesia to help us in writing this paper. 


\section{References}

[1] Mariana, Y. (2017). Pembuatan Hiasan Tas Dengan Teknik Bordir Aplikasi Seruni Tiga Dimensi Dari Kain Chiffon, Organdi Dan Satin. JPBD (Jurnal Penelitian Busana dan Desain), 1(1), 51-58.

[2] Tangchaiburana, S., \& Techametheekul, K. W. (2017). Development model of web design element for clothing e-commerce based on the concept of mass customization. Kasetsart journal of social sciences, 38(3), 242-250.

[3] Sun, Q. and Sun, X. (2021) 'Research on the Technology of Mass Customization of Clothing', International Journal of Modeling and Optimization, 11(3), pp. 86-93.

[4] Kiangala, S. K. and Wang, Z. (2021) 'An effective adaptive customization framework for small manufacturing plants using extreme gradient boosting-XGBoost and random forest ensemble learning algorithms in an Industry 4.0 environment', Machine Learning with Applications. Elsevier Ltd., 4(February), p. 100024.

[5] Noor Santi, R. C. (2018) 'Perancangan Interaksi Pengguna (User Interaction Design) Menggunakan Metode Prototyping', Jurnal Teknik Informatika, 9(2), pp. 108-113.

[6] Iqbal, S. Z., \& Idrees, M. 2017. Z-SDLC Model a New Model for Software Development Life Cycle (SDLC). International Journal of Engineering and Advanced Research Technology (IJEART), 3(2), pp. 8.

[7] Kumar, N., Zadgaonkar, A. S., \& Shukla, A. 2013. Evolving a new software development life cycle model SDLC-2013 with client satisfaction. International Journal of Soft Computing and Engineering (IJSCE), 3(1), pp. 2231-2307.

[8] Kondylakis, H., Katehakis, D. G., Kouroubali, A., Logothetidis, F., Triantafyllidis, A., Kalamaras, I., ... \& Tzovaras, D. 2020. COVID-19 Mobile Apps: A Systematic Review of the Literature. Journal of medical Internet research, 22(12), e23170.

[9] Islam, M. N., Islam, I., Munim, K. M., \& Islam, A. N. 2020. A review on the mobile applications developed for COVID-19: An exploratory analysis. IEEE Access, 8, pp. 145601-145610.

[10] valentino tansen, febryan, Mulyawan, B. and dolok lauro, M. (2018) 'Pembuatan Aplikasi E-Commerce Customize Pakaian Dan Prediksi Stok Dengan Menggunakan Metode Regresi Linear Sederhana', pp. 163-168.

[11] Suryadjaja, P. S., Hutagalung, M., \& Sutarto, H. Y. (2020). Modeling traffic flows with Fluid Flow Model. International Journal of Informatics, Information System and Computer Engineering, 1(1), 1-12.

[12] Supatmi, S., Goonjur M. K., \& Sumitra, I. D. (2020). Enhanced the Weighted Centroid Localization Algorithm Based on Received Strength Signal in Indoor Wireless Sensor Network. International Journal of Informatics, Information System and Computer Engineering (INJIISCOM), 1(1), 13-22

[13] Pangaribuan, I., Rahman, A., \& Mauluddin, S. (2020). Computer \& Network Equipment Management System (CNEMAS) Application Measurement. International Journal of Informatics, Information System and Computer Engineering (INJIISCOM), 1(1), 25-35.

[14] Singgih, I. K. (2020). Air Quality Prediction in Smart City's Information System. International Journal of Informatics, Information System and Computer Engineering (INJIISCOM), 1(1), 35-46. 
[15] Iida, H., \& Khalid, M. N. A. (2020). A Paradigm Shift from Optimal Play to Mental Comfort: A Perspective from the Game Refinement Theory. International Journal of Informatics, Information System and Computer Engineering (INJIISCOM), 1(1), 47-78.

[16] Hadiana, A. I. (2020). Fog Computing Architecture for Indoor Disaster Management. International Journal of Informatics, Information System and Computer Engineering (INJIISCOM), 1(1), 79-90.

[17] Atmaja, B. T., Akagi, M., \& Elbarougy, R. (2020). Dimensional Speech Emotion Recognition from Acoustic and Text Features using Recurrent Neural Networks. International Journal of Informatics, Information System and Computer Engineering (INJIISCOM), 1(1), 91-102.

[18] Uriawan, W. (2020). SWOT Analysis of Lending Platform from Blockchain Technology Perspectives. International Journal of Informatics, Information System and Computer Engineering (INJIISCOM), 1(1), 103-116.

[19] Febriani, L. I., Nurhashiva, C., Veronica, J., Ragadhita, R., Nandiyanto, A. B. D., \& Kurniawan, T. (2020). Computation Application: Techno-Economic Analysis on the Production of Magnesium Oxide Nanoparticles by Precipitation Method. International Journal of Informatics, Information System and Computer Engineering (INJIISCOM), 1(1), 117-128.

[20] Kanai, H., \& Kumazawa, A. (2021). An Information Sharing System for Multi-Professional Collaboration in the community-based integrated healthcare system. International Journal of Informatics, Information System and Computer Engineering (INJIISCOM), 2(1), 114.

[21] Purnomo, H., Fitrah, F. R., Maulana, R., \& Pratadina, M. M. (2021). Implementation of Information System in Indonesian Traditional Beverage Businesses. International Journal of Informatics, Information System and Computer Engineering (INJIISCOM), 2(1), 15-24.

[22] Supriyadi, A., Wang, T., Juwita, M. R., Gunaningrat, R., Safitri, S., \& Cirella, G. T. (2021). Sustainability Policy in Indonesia: Case Study Economic Structure and Determinants in Banjar Municipality. International Journal of Informatics, Information System and Computer Engineering (INJIISCOM), 2(1), 25-46.

[23] Puspitawati, L., Nurhasanah, A., \& Khaerunnisa, A. S. (2021). Utilization of Communication Technology for Business. International Journal of Informatics, Information System and Computer Engineering (INJIISCOM), 2(1), 47-54.

[24] Malik, S., Singh, S., Singh, N. M., \& Panwar, N. (2021). Diagnosis of COVID-19 Using Chest X-ray. International Journal of Informatics, Information System and Computer Engineering (INJIISCOM), 2(1), 55-64.

[25] Kurniadianti, Y. S., Ziva, A. Z., Suryana, Y. K., Ragadhita, R., Nandiyanto, A. B. D., \& Kurniawan, T. (2021). Computation in the Analysis of Techno-Economic of the Production of Al2O3 (Aluminum Oxide) Nanoparticles through Precipitation Method. International Journal of Informatics, Information System and Computer Engineering (INJIISCOM), 2(1), 65-76.

[26] Kumar, G., Gupta, S., Agarwal, D., \& Tiwari, A. (2021). Virtual Voting System. International Journal of Informatics, Information System and Computer Engineering (INJIISCOM), 2(1), 77-82. 
[27] Tolmatti, S. S., Jadhav, S. J., Jadhav, S. S., \& Maske, M. M. (2021). Concrete Mix Design Using Particle Packing Method: Literature Review, Analysis, and Computation. International Journal of Informatics, Information System and Computer Engineering (INJIISCOM), 2(1), 83-102

[28] Maulana, H., Ginting, S. L. B., Aryan, P., Fadillah, M. R., \& Kamal, R. N. (2021). Utilization of Internet of Things on Food Supply Chains in Food Industry. International Journal of Informatics, Information System and Computer Engineering (INJIISCOM), 2(1), 103-112.

[29] Veronica, J., Febriani, L. I., Nurhashiva, C., Ragadhita, R., \& Nandiyanto, A. B. D., Kurniawan, T. (2021). Practical Computation in the Techno-Economic Analysis of the Production of Magnesium Oxide Nanoparticles using Sol-gel Method. International Journal of Informatics Information System and Computer Engineering (INJIISCOM), 2(2), 112.

[30] Ginting, S. L. B., Maulana, H., Priatna, R. A., Fauzzan, D. D., \& Setiawan, D. (2021). Crowd Detection Using YOLOv3-Tiny Method and Viola-Jones Algorithm at Mall. International Journal of Informatics, Information System and Computer Engineering (INJIISCOM), 2(2), 13-22.

[31] Pratama, A. F. (2021). Sustainable and Digitized Certification of Palm Oil Production: Its Impact on the Environment in Indonesia. International Journal of Informatics, Information System and Computer Engineering (INJIISCOM), 2(2), 23-30.

[32] Hermawan, Y. A., Warlina, L., \& Mohd, M. (2021). GIS-based urban village regional fire risk assessment and mapping. International Journal of Informatics, Information System and Computer Engineering (INJIISCOM), 2(2), 31-43. 